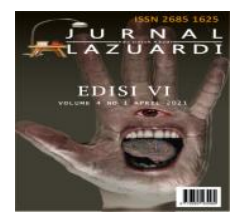

\title{
PROPOSISI KONDISIONAL DALAM IKLAN LAYANAN MASYARAKAT MASA PANDEMIC COVID-19
}

\author{
Firmina Angela Nai \\ Universitas Nusa Cendana-Jln. Adisucipto-Kota Kupang-Indonesia \\ firminanai@gmail.com
}

\begin{abstract}
Abstrak
Meskipun penelitian ini tidak berfokus pada kaidah-kaidah linguistik yang merupakan media utama iklan, namun pembahasan tentang konstruksi merupakan salah satu aspek penting dalam penelitian ini. Salah satu konstruksi kalimat adalah proposisi atau penalaran. Samhis Setiawan (2021) dengan mengutip para ahli menegaskan bahwa proposisi merupakan satu tutur atau pernyataan yang melukiskan beberapa keadaan yang belum tentu benar atau salah dalam bentuk sebuah kalimat berita. Proposisi adalah istilah yang dipergunakan dalam analisis logika. Keadaan dan peristiwa-peristiwa itu pada umumnya melibatkan pribadi atau orang yang dirujuk oleh ujaran dalam kalimat. Terdapat 3 bentuk proposisi yakni proposisi kategorik, proposisi hipotesis, dan proposisi disyungtif. Salah satu jenis dalam proposisi hipotesis disebut proposisi kondisional. yang menyatakan suatu kondisi hubungan ketergantungan antara dua proposisi. Hubungan tersebut menunjukkan bahwa proposisi yang satu pasti mengikuti proposisi yang lainnya karena adanya suatu kondisi tertentu. Artinya, bila syarat terpenuhi maka kebenaran terjadi. Sebaliknya, jika syarat tidak terpenuhi maka kebenaran tidak terjadi. Suatu proposisi kondisional biasanya ditandai dengan "Jika...Maka", "Kalau...Maka", "Bila...Maka", "Apabila...Maka”, "Andaikata...Maka”. Melalui proposisi kondisional serta makna yang terkandung di dalamnya Pemerintah, menawarkan sebuah kondisi yang baik agar masyarakat hidup secara sehat selama dan pasca Pandemic Covid-19.
\end{abstract}

\section{Kata Kunci: proposisi, kondisional, konstruksi}

\section{Abstract}

Although this research does not focus on linguistic rules which are the main media of advertising, the discussion about construction is one of the important aspects in this research. One sentence construction is a proposition or reasoning. Samhis Setiawan (2021) by citing experts asserts that a proposition is a speech or statement that describes several conditions that are not necessarily true or false in the form of a news sentence. Proposition is a term used in logical analysis. These circumstances and events generally involve the person or person referred to by the utterance in the sentence. There are 3 forms of propositions, namely categorical propositions, hypothetical propositions, and disjunctive propositions. One type of hypothetical proposition is called a conditional proposition. which states a condition of a dependent relationship between two propositions. This relationship shows that one proposition must follow the other propositions because of certain conditions. That is, if the conditions are met then the truth occurs. Conversely, if the conditions are not met then the truth does not occur. A conditional proposition is usually marked with "If...Then", "If...Then", "If...Then", 
"If...Then", "Suppose...Then". Through conditional propositions and the meanings contained in them, the Government offers good conditions so that people live healthily during and after the Covid-19 Pandemic.

Keywords: proposition, conditional, construction

\section{PENDAHULUAN}

\subsection{Latar Belakang}

Fokus utama penelitian adalah pada konstruksi kalimat yang digunakan dalam penyusunan iklan-iklan layanan masyarakat pada masa pandemic Covid-19. Subjek penelitian ini adalah iklan yang didesain dalam rangka memfasilitasi masyarakat untuk turut memutuskan mata rantai penyebaran Covid-19. Berdasarkan amatan peneliti pada berbagai iklan yang dikeluarkan oleh Lembaga atau Badan Pemerintah di berbagai media komunikasi, konstruksi kalimat yang digunakan pada umumnya berisi negosiasi sosial antara Pemerintah atau Lembaga berwenang lainnya dengan berbagai elemen masyarakat. Negosiasi sosial tersebut berangkat dari ungkapan yang sangat halus berupa himbauan dan ajakan, sampai pada tataran yang sangat keras seperti larangan, perintah, bahkan paksaan dan ancaman. Berikut ini dipaparkan 2 contoh iklan layanan masyarakat yang menggambarkan pola-pola proposisi kondisional.

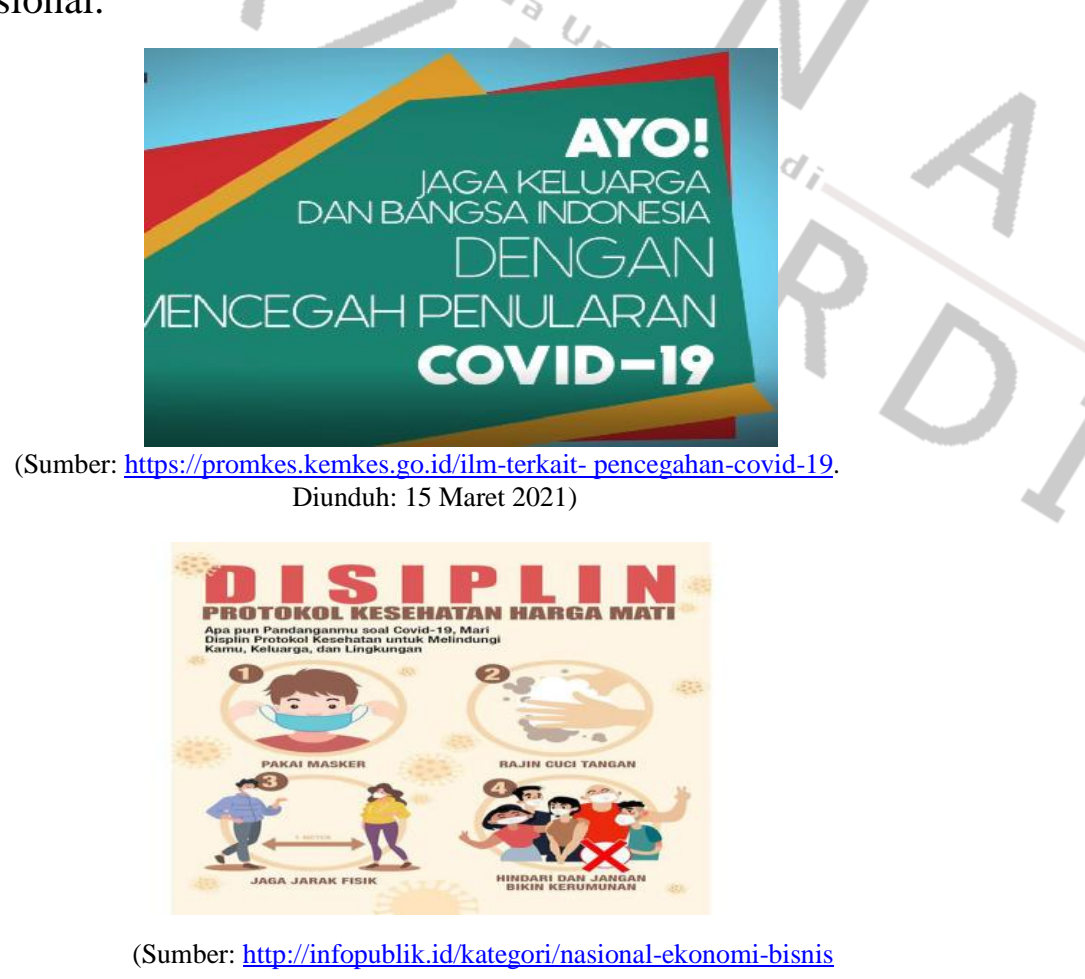


$\underline{\text { Dua contoh iklan di atas menggambarkan pola-pola proposisi dalam iklan layanan }}$ masyarakat pada masa pandemic covid-19 yang secara kondisional berisi ajakan dan ancaman agar masyarakat mengubah kebiasaan hidup. Meskipun menjadikan konstruksi kalimat dalam iklan layanan masyarakat sebagai media pengantar pesan kepada masyarakat, teori utama penelitian ini bukanlah teori komunikasi massa. Teori utama (grand theory) yang dijadikan landasan berpijak penelitian ini adalah teori wacana. Alasan utamanya adalah focal point penelitian ini adalah pada aspek pembelajaran yang sedang dicanangkan Pemerintah kepada masyarakat yang masih terkungkung dalam belenggu pandemic Covid-19.

Pembahasan tentang wacana merupakan salah satu aspek penting dalam penelitian ini. Bolen (dalam Rani, Dkk. 2004, tersaji melalui http://eprints.umm,ac.id, dikutip tanggal 03 Agustus 2021) mengatakan bahwa struktur wacana iklan dapat dilihat dari proposisinya. Struktur iklan mempunyai tiga unsur pembentuk yaitu butir utama iklan, badan iklan, dan penutup. Butir utama iklan bertujuan untuk menarik perhatian, maka dibutuhkan pesan-pesan iklan yang menarik dan penting sehingga membuat perhatian calon konsumen menjadi tertarik. Oleh karena tujuan penelitian ini adalah menganalisis konstruksi proposisional yang merupakan bagian penting dalam penalaran atau logika berbahasa akan menjadi aspek utama dalam pembahasan masalah pertama.

\subsection{Rumusan Masalah}

Berdasarkan latar belakang di atas, maka masalah utama dalam penelitian ini adalah: Bagaimanakah pola-pola proposisi kondisional yang digunakan dalam iklan layanan masyarakat pada masa pandemic Covid-19?

\subsection{Tujuan Penelitian}

Tujuan penelitian ini adalah untuk mengeksplorasi pola-pola konstruksi proposisi kondisional dalam iklan layanan masyarakat. Amatan khusus adalah pada kata-kata dan pola konstruksi kalimat dalam iklan tersebut bertujuan untuk memperoleh makna yang terkandung di dalamnya. Makna-makna tersebut akan memberikan gambaran tentang pesan-pesan penting dari Pemerintah dalam rangka melakukan negosiasi sosial dengan seluruh lapisan masyarakat dalam rangka membentuk tatanan kehidupan yang baru (New Normal). 


\section{METODE PENELITIAN}

\subsection{Prosedur Penelitian}

Penelitian ini menggunakan metode deskriptif-kualitatif yang tujuannya untuk mengeksplorasi pola-pola proposisi kondisional dalam iklan layanan masyarakat. Amatan khusus adalah pada kata-kata dan pola konstruksi kalimat dalam iklan tersebut bertujuan untuk memperoleh makna yang terkandung di dalamnya. Makna-makna tersebut akan memberikan gambaran tentang pesan-pesan penting dari Pemerintah dalam rangka melakukan negosiasi sosial dengan seluruh lapisan masyarakat dalam rangka membentuk tatanan kehidupan yang baru (New Normal).

Tahapan penelitian sebagai berikut:

(1) Menganalisis data tentang pola-pola proposisi kondisional dalam iklan layanan masyarakat pada masa pandemic Covid-19;

(2) Menganalisis makna konstruksi yang digunakan dalam iklan layanan masyarakat pada masa pandemic Covid-19;

(3) Menyimpulkan hasil penelitian.

\subsection{Data dan Sumber Data}

Data penelitian ini adalah iklan layanan masyarakat pada masa pandemic Covid-19. Media elektronik maupun nonelektronik yang tersaji secara online maupun offline.

\subsection{Teknik Pengumpulan Data}

2.3.1 Mengumpulkan iklan layanan masyarakat yang tersaji secara online maupun offline dari berbagai media;

2.3.2 Mengelompokkan jenis-jenis iklan berdasarkan pola proposisinya.

\subsection{Teknik Analisis Data}

Dalam rangka penelitian ini, teknik analisis data yang dilakukan adalah sebagai berikut:

a. Menyajikan data hasil penelitian;

b. Mendeskripsikan data hasil pengelompokkan berdasarkan pola proposisinya;

c. Memaparkan hasil penelitian; dan

d. Menarik simpulan.

\section{ACUAN TEORI}

\subsection{Konstruksi Proposisional}

Konstruksi adalah sebuah susunan atau sebuah bangunan yang dalam bidang linguistik diartikan sebagai susunan dan hubungan kata dalam kalimat atau kelompok kata 
(Tersaji dalam Kamus Besar Bahasa Indonesia versi online pada laman: https://kbbi.web.id/konstruksi, dikutip Tanggal 03 Agusutus 2021). Sebagai sebuah susunan kalimat, konstruksi proposisional yang menjadi fokus utama, maka penelitian ini akan menyoroti konstruksi proposisi kondisional sebagai salah satu aspek dalam wacana iklan.

Wacana iklan biasanya persuasif apabila yang diiklankan berkaitan dengan barang atau produk yang akan dijual ke konsumen, yakni kalangan pembaca iklan tersebut. Berkaitan dengan hal tersebut, maka bahasa memegang peranan yang sangat penting dalam rangka menyentuh target pasar dan menggerakkan masyarakat pembaca dalam mengenal dan memahami karakteristik produk yang ditawarkan melalui iklan tersebut. Anonimous (melalui https://eprints.uny.ac.id/) mengutip (Mulyana, 2005) yang mengatakan bahwa bahasa iklan harus ringkas dan tegas, yang berarti harus fokus dan biasanya hanya menyampaikan satu selling point. Iklan yang padat tidak akan bertele-tele, dan iklan yang baik menjangkau point yang umum. Bahasa iklan juga harus bersifat langsung, karena semakin ketat teksnya akan semakin mudah dipahami dan semakin besar dampaknya. Kata-kata dan gambar saling bekerja sama untuk menghasilkan konsep kreatif. Pernyataan Mulyana (2005) bahwa bahasa dalam iklan harus ringkas dan tegas serta fokus pada satu tujuan yang ingin dicapai, sejalan dengan upaya peneliti dalam mencari makna iklan dalam konstruksi proposisi kalimat yang digunakan. Sejalan dengan Mulyana (2005), Suwandi (2008, dalam Anonimous, 2021, tersaji melalui https://eprints.uny.ac.id/) mengatakan bahwa iklan disusun dengan bahasa yang komunikatif. Melalui wacana yang singkat, padat, dan persuasif, iklan berusaha menyampaikan pesan sesuai dengan karakteristik media dan tipe pembacanya. Kekomunikatifan bahasa iklan terlihat pada pilihan kata, struktur kalimat, koherensi, dan urutan argumentasi. Ada empat karakteristik umum bahasa iklan yang berbeda dengan penggunaan bahasa untuk keperluan lain. Karakteristik itu adalah (1) bahasa iklan disunting sesuai dengan tujuannya; (2) bahasa iklan kaya dan menawan, yang secara spesifik bermaksud menarik dan mendapatkan perhatian khalayak; (3) bahasa iklan menuntut perhatian khalayak untuk melengkapi iklan tersebut; dan (4) bahasa iklan bersifat sederhana.

Bolen (dalam Rani, Dkk. 2004, tersaji melalui http://eprints.umm,ac.id, dikutip tanggal 03 Agustus 2021) mengatakan bahwa struktur wacana iklan dapat dilihat dari proposisinya. Struktur iklan tersebut mempunyai tiga unsur pembentuk yaitu butir utama iklan, badan iklan, dan penutup. Butir utama iklan bertujuan untuk menarik perhatian, maka dibutuhkan pesanpesan iklan yang menarik dan penting sehingga membuat perhatian calon konsumen menjadi 
tertarik. Oleh karena tujuan penelitian ini adalah menganalisis konstruksi behavioristik dalam iklan layanan masyarakat maka proposisi yang merupakan bagian penting dalam penalaran atau logika berbahasa akan menjadi aspek utama dalam pembahasan masalah pertama.

\subsection{Jenis-Jenis Proposisi}

Samhis Setiawan (2021, melalui https://www.gurupendidikan.co.id/ dikutip tanggal 04 Agustus 2021) dengan mengutip para ahli menegaskan bahwa proposisi merupakan satu tutur atau pernyataan yang melukiskan beberapa keadaan yang belum tentu benar atau salah dalam bentuk sebuah kalimat berita. Proposisi adalah istilah yang dipergunakan dalam analisis logika. Keadaan dan peristiwa-peristiwa itu pada umumnya melibatkan pribadi atau orang yang dirujuk oleh ujaran dalam kalimat. Sebuah proposisi terdiri atas empat unsur, dua di antaranya merupakan materi pokok proposisi, sedangkan dua yang lain sebagai hal yang menyertainya. Empat unsur yang dimaksudkan ialah term sebagai subjek, term sebagai predikat, kopula dan quantor. Samhis Setiawan (2021) selanjutnya menjelaskan 3 bentuk proposisi yakni proposisi kategorik, proposisi hipotesis, dan proposisi disyungtif.

Proposisi kategorik adalah proposisi yang mengandung pernyataan tanpa adanya syarat dan yang paling sederhana terdiri dari satu term subyek, satu term predikat, satu kopula dan satu quantifier. Subyek adalah sebuah term yang menjadi pokok pembicaraan. Predikat adalah term yang menerangkan subjek. Kopula adalah kata yang menyatakan hubungan antara term subyek dan term predikat. Quantifier adalah kata yang menunjukkan banyaknya satuan yang diikat oleh term subyek.

Contoh: Sebagian manusia adalah pemabuk

$\begin{array}{llll}1 & 2 & 3 & 4\end{array}$

1: Quantifier

2: Term Subjek

3: Kopula

4: Term Predikat

Permasalahan yang ditunjuk dalam quantifier biasanya menjadi indikator jenis preposisi kategorik seperti, quantifier seluruh, semua, menunjuk jenis proposisi universal; quantifier sebagian, kebanyakan, dan lain-lain, menunjuk jenis proposisi partikular, dan quantifier seorang, sebuah, dan lain-lain, menunjuk proposisi singular. Kopula, adalah kata yang menegaskan hubungan term subjek dan term predikat dan term predikat baik hubungan menyetujui maupun hubungan mengingkari. Kopula menentukan kualitas proposisinya. Bila 
ia menyetujui, proposisi positif dan bila mengingkari disebut proposisi negatif. Berdasarkan kopula, terutama kombinasi antara kuantitas dan kualitas proposisi maka dikenal enam macam proposisi, yaitu :

Universal positif, seperti : Semua manusia akan mati

Partikular positif, seperti : Sebagian manusia adalah guru

Singular positif, seperti : Rudi adalah pemain bulu tangkis

Universal negatif, seperti : Semua kucing bukan burung

Partikular negatif, seperti : Beberapa mahasiswa tidak lulus

Singular negatif, seperti : Fatimah bukan gadis pemalu

Proposisi hipotesis, merupakan proposisi yang sifat pengakuan atau pengingkaran yang terkandung di dalamnya adalah sebuah syarat. Berdasarkan syarat tersebut maka proposisi hipotesis dibagi menjadi:

(1) Proposisi Kondisional: proposisi yang menyatakan suatu kondisi hubungan ketergantungan antara dua proposisi. Hubungan tersebut menunjukkan bahwa proposisi yang satu pasti mengikuti proposisi yang lainnya karena adanya suatu kondisi tertentu. Artinya, bila syarat terpenuhi maka kebenaran terjadi. Sebaliknya, jika syarat tidak terpenuhi maka kebenaran tidak terjadi. Suatu proposisi kondisional biasanya ditandai dengan “Jika...Maka”, “Kalau...Maka”, “Bila...Maka”, “Apabila...Maka”, “Andaikata, Maka”.

Contoh: Jika hujan turun, maka jalan menjadi basah.

Setiap proposisi atau pernyataan kondisional terdiri dari dua komponen. Komponen yang satu disebut anteseden dan komponen lainnya disebut konsekuen. Anteseden adalah pernyataan setelah jika atau sebelum maka. Konsekuen adalah pernyataan setelah maka. Dalam contoh di atas, antesedennya adalah hujan turun, konsekuennya adalah jalan menjadi basah. Kadang-kadang kata maka dihilangkan atau tidak dinyatakan. Susunan anteseden dan konsekuen pun kadang-kadang dibalik. Misalnya, Jalan menjadi basah jika hujan turun.

Contoh tersebut menyatakan suatu hubungan kausal antara hujan turun dan jalan menjadi basah.

(2) Proposisi Disyungtif: proposisi yang mengandung kemungkinan-kemungkinan atau pilihan-pilihan. Proposisi disyungtif biasanya ditandai dengan atau, atau ...atau.

Contoh: Ani atau Ana yang tidak jujur. Atau

kamu diam atau ayahmu akan terus marah 
Proposisi disyungtif dibedakan menjadi proposisi disyungtif dalam arti sempit dan arti luas. Dalam arti sempit hanya mengandung dua kemungkinan, tidak lebih dan tidak kurang. Kedua kemungkinan itu tidak dapat sama-sama benar. Dan dua kemungkinan itu hanya satu yang benar. Jika kemungkinan yang satu benar maka kemungkinan yang lain pasti salah.

Contoh: Ayah ada di kantor atau di...

Jika selanjutnya dikatakan Ayah ada di rumah, maka Ayah tidak ada di kantor adalah pasti benar.

Dalam arti luas pun mengandung pilihan antara dua kemungkinan. Namun. kedua kemungkinan itu dapat sama-sama benar. Jika satu kemungkinan benar, kemungkinan yang lain dapat benar juga karena dapat dikombinasikan.

\section{Contoh: Dia yang pergi atau saya yang...}

Jika selanjutnya dikatakan Dia yang pergi, kita tidak dapat memastikan bahwa Saya tidak pergi. Ada kemungkinan bahwa dia dan saya pergi bersama-sama.

(3) Proposisi Konjungtif: proposisi yang memiliki dua predikat, yang tidak mungkin samasama memiliki kebenaran pada saat yang bersamaan. Proposisi ini biasanya ditandai dengan tidak mungkin sekaligus ... dan

Contoh: Engkau tidak dapat sekaligus berada di Jakarta dan di Surabaya pada saat yang sama.

Kebenaran suatu proposisi konjungtif tergantung pada suatu oposisi eksklusif yang benar, yang berada di antara bagian-bagiannya. Bagian-bagian dan suatu proposisi konjungtif disebut konjungsi. Proposisi-proposisi semacam ini dapat dijabarkan menjadi dua proposisi hipotetis atau menjadi suatu kombinasi yang terdiri dari proposisi hipotesis dan proposisi kategoris. Contoh: Jika engkau berada di Jakarta, engkau tidak berada di Surabaya.

\section{Jika engkau berada di Surabaya, engkau tidak berada di Jakarta}

Struktur wacana yang digunakan dalam iklan dengan memperhatikan aspek logika berbahasa dalam bentuk proposisi, juga digunakan peneliti dalam menganalisis konstruksi proposisional. Hal ini dilakukan mengingat konstruksi yang dimaksudkan di sini adalah konstruksi kalimat iklan yang merupakan sebuah wacana.

Proposisi hipotesis memiliki 3 jenis sebagaimana yang dikutip peneliti dari Samhis Setiawan (2021, melalui https://www.gurupendidikan.co.id/. Ketiga jenis proposisi hipotesis tersebut adalah proposisi kondisional, proposisi disyungtif, dan proposisi konjungtif. Jenis yang sesuai untuk menganalisis konstruksi proposisional adalah proposisi kondisional. 
Proposisi ini menjelaskan sifat ketergantungan antara dua proposisi, yakni proposisi yang satu pasti mengikuti proposisi yang lain karena ada suatu kondisi tertentu. Bila syarat terpenuhi maka kebenaran terjadi, sebaliknya, jika syarat tidak terpenuhi maka kebenaran tidak terjadi yang dirumuskan melalui pola ...jika...maka... . Dengan memilih proposisi hipotesis jenis preposisi kondisional, peneliti menemukan relasi yang sejajar antara logika berbahasa dengan jenis proposisi kondisional dengan prinsip pengondisian yang digagas Edward Thorndike (1913 dalam Schunk, 2012: 101).

\section{HASIL DAN PEMBAHASAN}

\subsection{Hasil Penelitian}

Hasil penelusuran di internet dan dokumentasi lapangan berupa spanduk dan baliho iklan layanan masyarakat pada masa Pandemi Covid-19, peneliti menemukan bahwa terdapat 2 jenis konstruksi proposisi kalimat dalam iklan-iklan tersebut. Konstruksi tersebut adalah proposisi kondisional berpola persuasif dengan berbagai varian persuasinya. Konstruksi kedua dikategorikan sebagai konstruksi proposisi kondisional berpola intimidatif dengan berbagai varian intimidasi atau treatmennya.

\subsubsection{Konstruksi Proposisi Persuasif dalam Iklan Layanan Masyarakat pada Masa Pandemi Covid-19}

Persuasif adalah sebuah kata sifat atau sesuatu yang bersifat membujuk secara halus (supaya menjadi yakin). Pengertian ini dikutip dari https://kbbi.web.id/persuasif.html (tanggal 27 July 2021). Selanjutnya, brainly.co.id (dikutip tanggal 27 July 2021) menjelaskan kalimat persuasif dalam iklan adalah kalimat yang bersifat membujuk, mengajak atau mempengaruhi seseorang agar melakukan perintah/ajakan dalam iklan tersebut. Kalimat persuasif dalam iklan dengan makna membujuk merupakan ajakan yang sangat halus agar pembaca mau mengikuti ajakan, saran bahkan perintah atau larangan. Selain membujuk, kalimat persuasif juga bersifat mengajak agar pembaca mau bersama-sama mematuhi larangan atau perintah yang terdapat dalam kalimat iklan tersebut. Apabila hal yang diiklankan berkaitan dengan barang atau produk tertentu, maka sifat-sifat persuasi tersebut bertujuan agar khalayak pembaca meminati barang atau produk yang ditawarkan si pembuat iklan. Demikian halnya dengan sifat persuasi lain yang biasanya terdapat dalam iklan barang atau produk yakni mempengaruhi. Melalui susunan kata dan kalimat yang persuasif, si 
pembuat iklan berusaha mempengaruhi pembaca agar mau membeli dan memiliki barang atau produk yang ditawarkan melalui iklan tersebut.

Konstruksi persuasif dalam iklan layanan masyarakat pada masa Pandemi Covid-19 lebih banyak berisi negosiasi sosial antara Pemerintah dan atau lembaga lain yang berperan sebagai penentu kebijakan. Seluruh sifat persuasi seperti membujuk, mengajak, dan mempengaruhi masyarakat tercantum dalam konstruksi tersebut. Hal tersebut dapat dilihat pada contoh-contoh iklan berikut ini.

Gambar 4.1.1.a: Iklan Layanan Masyarakat Berkonstruksi Persuasif: Membujuk/Mengajak:

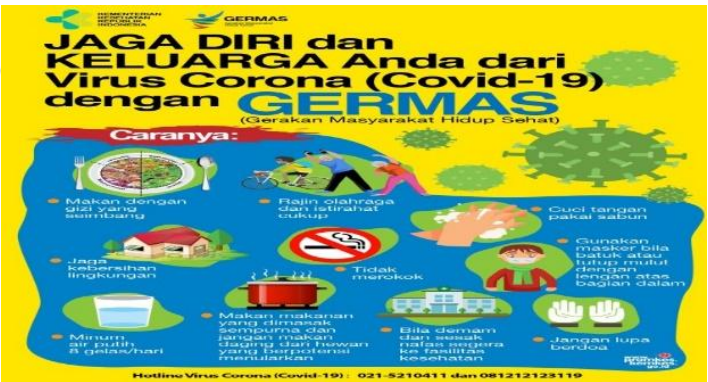

Sumber: https://manado.tribunnews.com/2020/04/13/35-gambar-poster-pencegahan-covid-19-

4.1.1.b Iklan Layanan Masyarakat Berkonstruksi Persuasif: Membujuk/Mengajak:

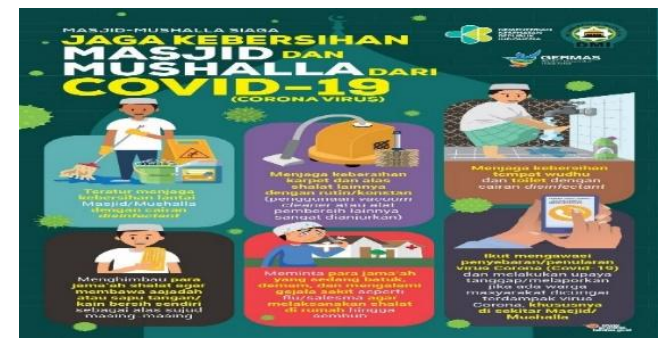

Sumber: https://manado.tribunnews.com/2020/04/13/35-gambar-poster-pencegahan-covid-194.1.1.c Iklan Layanan Masyarakat Berkonstruksi Persuasif: Membujuk/Mengajak:

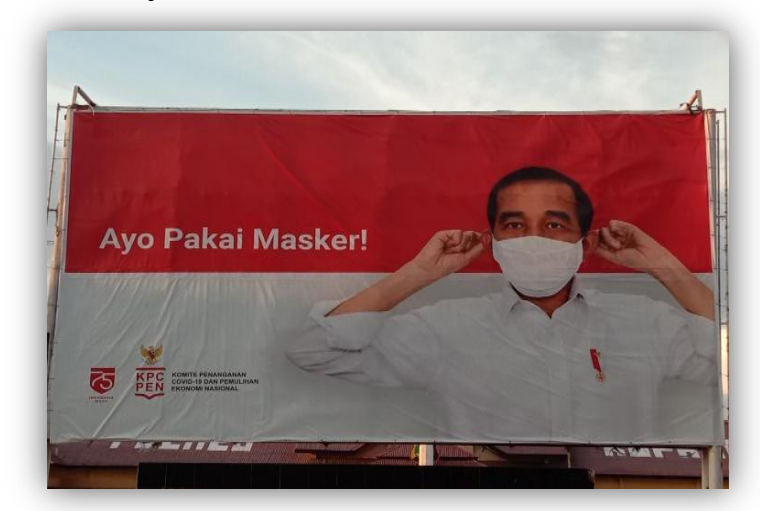

Spanduk diambil di Kompleks Polres Babau, Kabupaten Kupang (10 Maret 2021) 
Peneliti menampilkan 3 poster (Gambar 4.1.1.a, 4.1.1.b, 4.1.1.c) yang berisi iklan layanan masyarakat dengan konstruksi persuasif yang bersifat 'membujuk' atau 'mengajak'. Sebagaimana telah diutarakan pada latar belakang bahwa penelitian ini melidik konstruksi proposisional dalam iklan layanan masyarakat pada masa pandemic Covid-19.

Peneliti memilih padanan kata persuasi dalam arti memikat hati orang yang membaca iklan tersebut. Poster yang pertama berisi iklan layanan masyarakat yang berbunyi: "Jaga Diri dan Keluarga Anda dari Virus Corona (Covid-19) dengan GERMAS”. Membujuk atau mengajak dalam konstruksi di atas disusun secara halus dan memikat hati tanpa ada pilihan kata lain yang bersifat perintah atau komando.

Membujuk berasal dari kata dasar kata benda 'bujuk' yang dalam Kamus Besar Bahasa Indonesia dideskripsikan sebagai usaha untuk meyakinkan seseorang dengan katakata manis dan sebagainya bahwa yang dikatakan itu benar. Bujuk dipadankan dengan kata 'rayu'. Sedangkan 'membujuk' adalah sebuah tindakan (verba) yang berusaha meyakinkan seseorang bahwa yang dikatakannya itu benar (untuk memikat hati, menipu, dan sebagainya); merayu (Badan Pengembangan dan Pembinaan Bahasa, Kementerian Pendidikan dan Kebudayaan Republik Indonesia, 2016: melalui laman https://kbbi.kemdikbud.go.id/entri/bujuk). Dari arti kamus tersebut, pilihan arti kata membujuk yang sesuai untuk menjelaskan konstruksi persuasif adalah 'memikat hati'.

Membujuk atau merayu, adalah salah satu kiat atau strategi untuk memikat hati sebagaimana makna verba yang diemban kata tersebut. Dalam arti Kamus, kata 'membujuk' atau 'merayu' memiliki beberapa arti, yang salah satu di antaranya berarti 'memikat hati'. Arti ini menjadi semakin kuat dan penting dalam pilihan kata yang sesuai untuk digunakan dalam iklan layanan masyarakat, terutama sebagai alat negosiasi sosial pada masa pandemi Covid-19. Pada poster yang pertama di atas, konstruksi utamanya berbunyi: “Jaga Diri dan Keluarga Anda dari Virus Corona (Covid-19) dengan GERMAS". Pada konstruksi tersebut, pilihan kata "Jaga Diri dan Keluarga Anda" menjadi susunan kalimat bujukan yang pertama sehingga disebut konstruksi utama. Bujukan atau rayuan untuk menjaga diri tersebut dilengkapi pula dengan gambar dan kalimat-kalimat penjelasan yang merupakan cara yang dituntun oleh Pemerintah (sebagai pembuat iklan bujukan/rayuan) tersebut.

Susunan kalimat atau konstruksi bujukan yang dicantumkan dalam Gerakan Masyarakat Hidup Sehat di era Pandemi Covid-19 adalah: "Jaga Diri dan Keluarga Anda 
dari Virus Corona (Covid-19) dengan GERMAS". Pengiklan merinci 10 gerakan masyarakat tersebut sebagai berikut:

(1) "Makan dengan gizi yang seimbang";

(2) "Rajin olahraga dan istirahat yang cukup";

(3) "Cuci tangan pakai sabun";

(4) "Jaga kebersihan lingkungan";

(5) "Tidak merokok";

(6) "Gunakan masker bila batuk atau tutup mulut dengan lengan atas bagian dalam";

(7) "Minum air putih 8 gelas/hari";

(8) "Makan makanan yang dimasak sempurna dan jangan makan daging dari hewan yang berpotensi menularkan";

(9) "Bila demam dan sesak nafas segera ke fasilitas kesehatan";

(10) "Jangan lupa berdoa".

Ke-10 konstruksi di atas sesuai sebagai kalimat bujukan karena pilihan kata yang disusun semuanya berkonstruksi kata dasar saja. Konstruksi yang demikian akan berpengaruh pada intonasi ketika membaca, yakni intonasi yang datar tanpa nada perintah, larangan atau paksaan. Selain itu, jika dianalisis berdasarkan konstruksi sebuah wacana, maka ke-10 konstruksi di atas terkategori sebagai proposisi kondisional. Proposisi yang menyatakan suatu kondisi hubungan ketergantungan antara dua proposisi. Hubungan tersebut menunjukkan bahwa proposisi yang satu pasti mengikuti proposisi yang lainnya karena adanya suatu kondisi tertentu. Artinya, bila syarat terpenuhi maka kebenaran terjadi. Sebaliknya, jika syarat tidak terpenuhi maka kebenaran tidak terjadi. Suatu proposisi kondisional biasanya ditandai dengan "Jika...Maka", "Kalau...Maka", "Bila...Maka”, "Apabila...Maka", “Andaikata, Maka”. Meski tidak mencantumkan kondisi Jika...Maka..., secara eksplisit, ke10 konstruksi di atas termasuk konstruksi proposisi kondisional. Sebagai contoh, lengkapnya konstruksi di atas adalah...Jika ingin sehat, maka cucilah tangan pakai sabun ... .

Proposisi kondisional mensyaratkan suatu kondisi hubungan ketergantungan antara dua proposisi. Hubungan tersebut menunjukkan bahwa proposisi yang satu pasti mengikuti proposisi yang lainnya karena adanya suatu kondisi tertentu. Artinya, bila syarat terpenuhi maka kebenaran terjadi. Sebaliknya, jika syarat tidak terpenuhi maka kebenaran tidak terjadi. Namun dalam iklan (4.1.1.a) di atas hal tersebut yakni hubungan ketergantungan antara dua proposisi, tidak dirumuskan secara eksplisit. Hal tersebut dapat dilihat melalui analisis berikut:

\section{"Jaga Diri dan Keluarga Anda dari Virus Corona (Covid-19) dengan GERMAS"}


Secara kondisional, proposisi di atas tidak secara eksplisit menyatakan hubungan ketergantungan antara dua proposisi. Hal yang dinyatakan secara eksplisit adalah proposisi kedua yakni kebenarannya atau pengakuannya apabila proposisi syaratnya dilakukan dengan baik dan benar. Apabila dijabarkan secara lengkap dan lebih rinci, maka konstruksi iklan Gambar 4.1.1.a di atas berbunyi: ...”Jika Anda mau Menjaga Diri dan Keluarga dari Virus Corona, maka lakukan dengan Germas... yakni: “Gunakan masker bila batuk atau tutup mulut dengan lengan atas bagian dalam"...dan seterusnya.

Pola persuasi varian membujuk atau mengajak dalam iklan (4.1.1.a) di atas disusun dengan proposisi yang sederhana namun tetap tegas dalam rangka membujuk atau merayu masyarakat agar hidup sehat. Bujukan atau ajakan tersebut dirinci dalam 10 kalimat yang tetap berada dalam nuansa bujukan atau ajakan. Aspek proposisi kondisional yang berkonstruksi “Jika”...”Maka”...dinyatakan secara tidak eksplisit demi menjaga nuansa bujukan atau ajakan tersebut. Namun demikian, aura proposisi kondisional tetap ada meskipun dilesapkan dalam konstruksi iklan tersebut.

Iklan 4.1.1.a, "Jaga Diri dan Keluarga Anda dari Virus Corona (Covid-19) dengan GERMAS" di atas sangat jelas menggambarkan propisisi kondisional melalui konstruksi ...”jika”...”maka” yang dilesapkan dalam proposisi tersebut. Berdasarkan pola proposisi tersebut, jika masyarakat menjaga diri dengan Germas (Gerakan masyarakat untuk hidup sehat), maka masyarakat pasti akan terbebas dari paparan virus Covid-19. Sebagaimana sudah dibahas di atas, bahwa proposisi kondisional mensyaratkan suatu kondisi hubungan ketergantungan antara dua proposisi. Hubungan tersebut menunjukkan bahwa proposisi yang satu pasti mengikuti proposisi yang lainnya karena adanya suatu kondisi tertentu. Artinya, bila syarat terpenuhi maka kebenaran terjadi. Sebaliknya, jika syarat tidak terpenuhi maka kebenaran tidak terjadi.

Hampir sejalan dengan Gambar 4.1.1.a, Gambar 4.1.1.b, juga menyampaikan pesan serupa. “Jaga Kebersihan Masjid dan Mushalla dari Virus Covid-19”. Iklan ini juga merinci mekanisme “jaga” melalui konstruksi-konstruksi bujukan atau ajakan sebagai berikut:

(1) "Teratur menjaga kebersihan lantai Masjid dan Mushalla dengan cairan disinfectan";

(2) "Menjaga kebersihan karpet dan alas shalat lainnya dengan rutin dan konstan (penggunaan vacuum cleaner dan alat kebersihan lainnya sangat dianjurkan";

(3) "Menjaga kebersihan tempat wudhu dan toilet dengan cairan disinfektan"; 
(4) "Menghimbau para jamaah shalat untuk membawa sajadah atau saputangan/kain bersih sendiri sebagai alat sujud masing-masing";

(5) "Meminta para jamaah yang sedang batuk, demam, dan mengalami gejala sakit, seperti flu/salesma, agar melaksanakan shalat di rumah hingga sembuh";

(6) "Ikut mengawasi penyebaran/penularan virus corona (covid-19) dan melakukan upaya tanggap/melaporkan jika ada warga masyarakat dicurigai terdampak virus corona, di sekitar Masjid/Mushalla”.

Konstruksi di atas termasuk dalam kategori proposisi kondisional, meskipun aspek “Jika” dan "Maka” tidak dinyatakan secara eksplisit. Pola persuasi yang digunakan melalui pilihan kata yang hanya berkonstruksi kata dasar juga masih termasuk varian bujukan atau ajakan. Konstruksi seperti di atas, jika dibaca, tidak menunjukkan nuansa perintah atau paksaan.

Gambar 4.1.1.c merupakan data penelitian yang berkonstruksi persuasi dengan varian bujukan atau ajakan. Iklan layanan masyarakat dengan potret Presiden Jokowi merupakan iklan dengan konstruksi kalimat sangat sederhana yakni ajakan ...”Ayo Pakai Masker”... . Iklan tersebut menjadi sangat menarik oleh karena pesan atau amanat iklan tersebut justru terbaca dengan sangat lengkap pada gambar dan potret Bapak Presiden yang seolah-olah sedang mengajak masyarakat mengenakan masker dengan benar. Posisi tangan sedang berada di arah telinga, sambil mengucapkan ...”Ayo Pakai Masker"... .

Ajakan Bapak Presiden melalui kalimat yang sangat sederhana tersebut sesungguhnya tidak sesederhana itu. Hal tersebut dapat diikuti dari proposisi nonverbal yang diwujudkan melalui posisi tangan yang sedang memasangkan masker ke arah telinga yang seolah-olah sambil mengucapkan ajakan ...”Ayo Pakai Masker”... . Jika seluruh aspek nonverbal tersebut dikonritkan secara verbal, maka konstruksi kalimat tersebut akan berbunyi ..."Jika ingin sehat, ayo pakai masker"... .Hal ini kembali membenarkan bahwa konstruksi kalimat atau proposisi kondisional, selalu digunakan sebagai salah satu konstruksi dalam menyusun iklan layanan masyarakat yang mengemban makna negosiasi sosial dari Pemerintah atau Lembaga lainnya yang berperan membimbing masyarakat. Setelah gambar atau potret itu dibahasakan secara konkrit, maka konstruksi iklan di atas termasuk proposisi kondisional. 
4.1.1.d Iklan Layanan Masyarakat Berkonstruksi Persuasif: Memengaruhi:

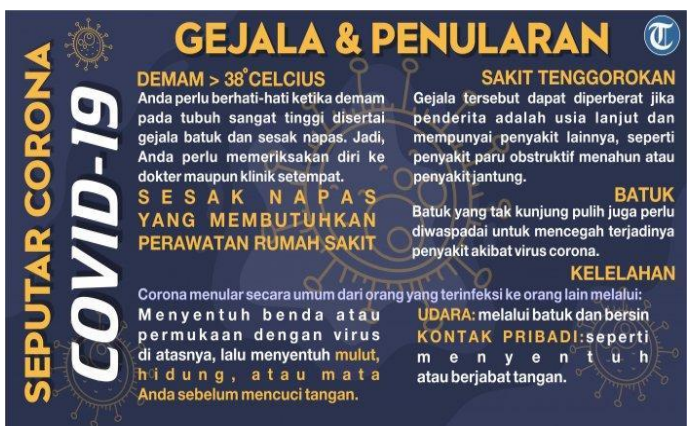

Sumber: https://manado.tribunnews.com/2020/04/13/35-gambar-poster-pencegahan-covid-19-

4.1.1.d Iklan Layanan Masyarakat Berkonstruksi Persuasif: Memengaruhi/Mengajak:

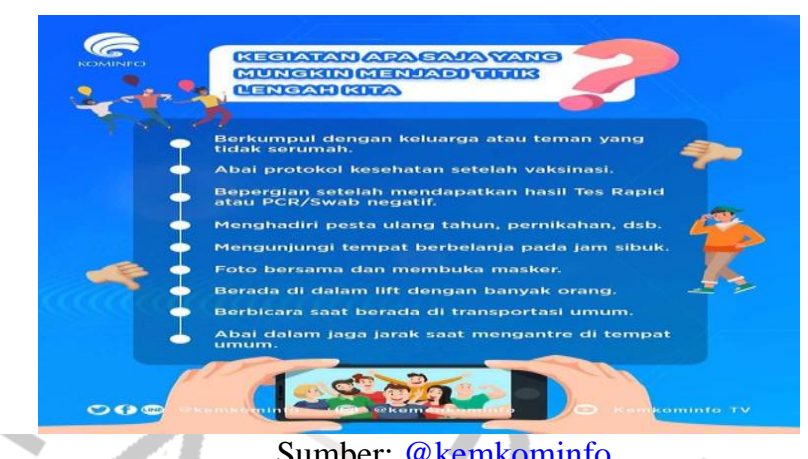

Selain varian mengajak atau membujuk, konstruksi persuasi dalam iklan layanan masyarakat di era pandemik Covid-19, juga bervarian memengaruhi atau memberi pengaruh kepada masyarakat. Peneliti menghimpun beberapa iklan dari media surat kabar offline dan elektronik dan menyajikan dua iklan untuk dianalisis berdasarkan pola proposisi kondisional.

Gambar 4.1.1.d berisi iklan yang cukup kompleks dalam memengaruhi masyarakat agar patuh pada protokol kesehatan. Iklan yang dimuat oleh Tribun News Manado tersebut berbunyi: “Seputar Corona, Covid-19. Gejala dan Penularan”. Wacana ini ditulis dengan menarik dan ukuran huruf yang cukup besar sehingga mudah dilihat pembaca dan terpengaruh untuk dibaca. Namun demikian, wacana tersebut bukanlah tubuh iklan atau hal utama yang mau diiklankan. Tubuh iklan ditulis dalam rincian sebagai berikut:

(1) Demam $>38^{\circ}$ Celcius: "Anda perlu berhati-hati ketika demam pada tubuh sangat tinggi disertai gejala batuk dan sesak napas. Jadi, Anda perlu memeriksakan diri ke dokter maupun klinik setempat";

(2) "Sesak napas yang membutuhkan perawatan rumah sakit";

(3) "Sakit tenggorokan: Gejala tersebut dapat diperberat jika penderita adalah usia lanjut dan mempunyai penyakit lainnya, seperti penyakit paru obstruktif menahun atau penyakit jantung"; 
(4) Batuk: "Batuk yang tak kunjung pulih juga perlu diwaspadai untuk mencegah terjadinya penyakit akibat virus corona";

(5) Kelelahan: "Corona menular secara umum dari orang yang terinfeksi ke orang lain melalui: Menyentuh benda atau permukaan dengan virus di atasnya, lalu menyentuh mulut, hidung atau mata Anda sebelum mencuci tangan; Udara: melalui batuk dan bersin; Melalui kontak pribadi seperti menyentuh atau berjabat tangan”.

Secara persuasif, iklan di atas ditulis dengan menggunakan proposisi kategorik. Proposisi kategorik adalah proposisi yang mengandung pernyataan tanpa adanya syarat dan yang paling sederhana terdiri dari satu term subyek, satu term predikat, satu kopula dan satu quantifier. Subyek adalah sebuah term yang menjadi pokok pembicaraan. Predikat adalah term yang menerangkan subjek. Kopula adalah kata yang menyatakan hubungan antara term subyek dan term predikat. Quantifier adalah kata yang menunjukkan banyaknya satuan yang diikat oleh term subyek.

Kepala iklan persuasif dengan varian memengaruhi di atas merupakan proposisi kategorik berjenis singular positif. Dikatakan demikian karena oleh karena kopula proposisi tersebut bersifat positif. Kopula, adalah kata yang menegaskan hubungan term subjek dan term predikat, baik hubungan menyetujui maupun hubungan mengingkari. Kopula menentukan kualitas proposisinya. Bila menyetujui, disebut proposisi positif dan bila mengingkari disebut proposisi negatif. Berdasarkan kopula, terutama kombinasi antara kuantitas dan kualitas proposisi, iklan di atas merupakan proposisi kategorik singular positif. Melalui kepala iklan yang berbunyi "Seputar Corona, Covid-19. Gejala dan Penularan", tubuh iklan tersebut secara singular positif menjelaskan berbagai hal tentang Covid-19 antara lain sebagai berikut: “Anda perlu berhati-hati ketika demam pada tubuh sangat tinggi disertai gejala batuk dan sesak napas”. Konstruksi persuasif varian memengaruhi tersebut terdiri dari:

“Anda perlu berhati-hati ketika demam pada tubuh sangat tinggi disertai gejala batuk dan sesak napas”

1: Term subjek: Anda

2: Kopula: perlu

3: Term predikat: berhati-hati

4: Term Keterangan: ketika demam pada tubuh sangat tinggi disertai gejala batuk dan sesak napas.

Proposisi tersebut merupakan kategorik singular positif karena kualitas term predikat yang menegaskan term subjek melalui kata "perlu” yang secara persuasi memengaruhi pembaca atau masyarakat untuk berhati-hati dengan gejala Covid-19. Konstruksi persuasi 
tersebut tidak menyaratkan pengingkaran, karena bersifat positif dan pasti disetujui atau diterima.

\subsubsection{Konstruksi Intimidatif dalam Iklan Layanan Masyarakat pada Masa Pandemic Covid-19}

Terdapat 3 arti kata intimidasi dalam Kamus besar Bahasa Indonesia (KBBI) yang masuk ke dalam kelas kata nomina (kata benda). Arti yang pertama adalah tindakan menakutnakuti (terutama untuk memaksa orang atau pihak lain berbuat sesuatu). Arti kedua adalah gertakan, dan arti ketiga adalah ancaman (Dikutip dari https://lektur.id tanggal 01 Oktober 2021). Ketiga arti kata intimidasi tersebut dikategorikan sebagai varian intimidasi, terutama melarang yakni memaksa orang atau pihak lain untuk berbuat atau tidak berbuat sesuatu. Varian lainnya adalah perintah yang juga dapat disamakan dengan gertakan agar orang atau pihak lain mau melakukan sesuatu dengan patuh dan taat kepada perintah tersebut.

Penelitian lapangan menunjukkan beberapa iklan layanan masyarakat pada masa pandemik Covid-19 dengan konstruksi intimidatif memiliki beberapa varian yakni larangan, instruksi atau perintah, serta ancaman yang dijabarkan sebagai berikut:

\subsection{2.a Iklan layanan Masyarakat Berkonstruksi Intimidatif: Larangan}

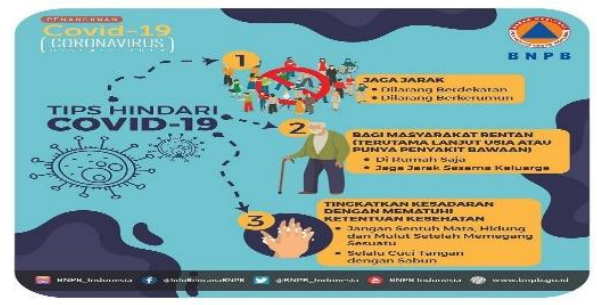

Sumber: https://manado.tribunnews.com/2020/04/13/35-gambar-poster-pencegahan-covid-19-

Iklan layanan masyarakat berkonstruksi intimidatif dengan varian larangan di atas dikeluarkan oleh BNPB dengan memberikan 3 tips hindari Covid-19 yakni pertama, "Jaga Jarak", kedua "Bagi Masyarakat Rentan (terutama lanjut usia atau punya penyakit bawaan), dan ketiga "Tingkatkan kesadaran dengan mematuhi ketentuan Kesehatan”. Ketiga tips tersebut merupakan tubuh iklan yang dilengkapi dengan rincian yang seluruhnya berupa larangan dengan rincian sebagai berikut:

(1) Jaga Jarak: "Dilarang Berdekatan" dan "Dilarang Berkerumun”;

(2) Bagi Masyarakat Rentan (terutama lanjut usia atau punya penyakit bawaan): " $D i$ rumah Saja" dan "Jaga Jarak sesama Keluarga";

(3) Tingkatkan kesadaran dengan mematuhi ketentuan Kesehatan: "Jangan sentuh mata, hidung, dan mulut setelah memegang sesuatu" dan "Selalu cuci tangan dengan sabun". 
Berdasarkan konstruksi proposisional, iklan di atas termasuk proposisi kondisional dengan kepala iklan yang berbunyi "Tips hindari Covid-19". Kepala iklan ini selanjutnya menjadi kondisi yang ditawarkan, jika Anda ingin sehat, maka Anda harus Jaga Jarak yang disertai dengan konstruksi intimidatif yakni "Dilarang Berdekatan"..."Dilarang Berkerumun". Meskipun konstruksi proposisi kondisional tidak dinyatakan secara eksplisit, oleh karena salah satu tuntutan Bahasa iklan, namun konstruksi "Jika" dan "Maka" tetap ada dalam kalimat iklan tersebut. Kalimat dan pilihan kata yang padat dan langsung ke tujuan, menjadi salah satu karakteristik Bahasa iklan layanan masyarakat. Mempertimbangkan hal ini maka, diksi "jika" dan "maka" dilesapkan dalam iklan tersebut.

\subsection{2.b Iklan layanan Masyarakat Berkonstruksi Intimidatif: Perintah/Instruksi}

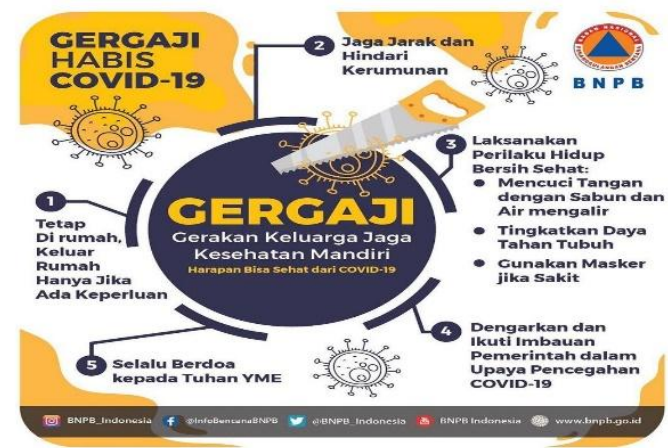

Sumber: https://manado.tribunnews.com/2020/04/13/35-gambar-poster-pencegahan-covid-19-

$\underline{\text { Selain varian larangan, konstruksi intimidatif juga memiliki varian perintah atau }}$ instruksi, seperti pada Gambar 4.1.2.b di atas. Dengan menggunakan ilustrasi berupa gambar gergaji, iklan tersebut menampilkan akronim GERGAJI atau Gerakan Keluarga Jaga Kesehatan Mandiri. Iklan intimidatif ini menggunakan kalimat: "Gergaji habis Covid-19" sebagai kepala iklan, yang disertai 5 kalimat rincian yang merupakan tubuh iklan yakni:

(1) "Tetap di rumah. Keluar rumah hanya jika ada keperluan";

(2) "Jaga jarak dan hindari kerumunan";

(3) "Laksanakan Perilaku Hidup Bersih Sehat: Mencuci Tangan dengan Sabun dan Air mengalir";

(4) "Dengarkan dan Ikuti imbauan Pemerintah dalam Upaya Pencegahan Covid-19";

(5) "Selalu Berdoa kepada Tuhan YME".

Pilihan kata yang digunakan dalam tubuh iklan di atas sangat jelas menunjukkan makna perintah atau instruksi kepada masyarakat untuk patuh pada protokol kesehatan. Ketegasan perintah itu telah dimulai dari kepala iklan yakni "Gergaji habis Covid-19". Meskipun merupakan sebuah akronim, pilihan kata GERGAJI yang ditunjang dengan gambar yang 
diposisikan sedang menggergaji, iklan ini sangat sarat dengan muatan perintah atau instruksi. Hal tersebut tampak pada 5 kalimat yang merinci perintah atau instruksi Pemerintah agar masyarakat tidak keluar rumah, jaga jarak dan hindari kerumunan, berperilaku bersih dan sehat, dengarkan dan ikuti anjuran Pemerintah, dan selalu berdoa.

Berdasarkan konstruksi proposisinya, iklan intimidatif dengan varian perintah atau larangan ini juga berkategori proposisi kondisional. Hampir sama dengan iklan-iklan yang telah dibahas di atas, konstruksi "Jika".."Maka" yang menjadi indikator utama proposisi ini sering dilesapkan, demi menyempurnakan salah satu syarat bahasa dalam iklan yakni singkat, padat, dan jelas. Sarat bahasa yang singkat dan padat itulah yang sering menjadi alasan utama pelesapan beberapa kata yang merupakan persyaratan sebuah kalimat yang atau proposisi yang lengkap dari aspek gramatikal. Apabila konstruksi proposisi kondisional tersebut dinyatakan secara lengkap, maka kepakla iklan tersebut berbunyi "Jika ingin hidup sehat, maka gergaji habis Covid-19”. Konstruksi tersebut juga terdapat dalam 5 rincian GERGAJI yakni:

(1) "Jika ingin terbebas dari Covid-19, maka tetap di rumah. Keluar rumah hanya jika ada keperluan";

(2) "Jika ingin terbebas dari Covid-19, maka jaga jarak dan hindari kerumunan";

(3) "Jika ingin terbebas dari Covid-19, maka laksanakan Perilaku Hidup Bersih Sehat: Mencuci Tangan dengan Sabun dan Air mengalir";

(4) "Jika ingin terbebas dari Covid-19, maka dengarkan dan Ikuti imbauan Pemerintah dalam Upaya Pencegahan Covid-19";

(5) "Jika ingin terbebas dari Covid-19, maka selalu Berdoa kepada Tuhan YME".

\subsection{2.c Iklan layanan Masyarakat Berkonstruksi Intimidatif: Ancaman:}

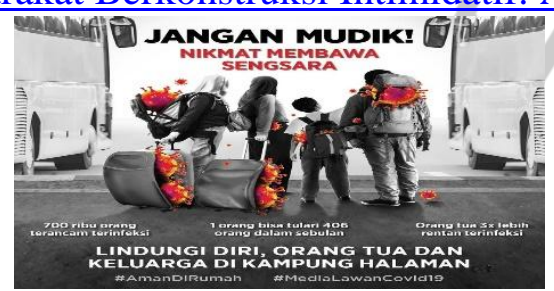

Sumber: https://manado.tribunnews.com/2020/04/13/35-gambar-poster-pencegahan-covid-19-

Varian berikut dari konstruksi intimidatif adalah ancaman. Hal tersebut tampak pada

iklan 4.1.2.c di atas. Iklan yang dikeluarkan Pemerintah pada Bulan Ramadhan tahun 2020 ini disampaikan dengan pilihan kata yang cukup tegas sebagai peringatan atau ancaman untuk melakukan mudik yang menjadi salah satu tradisi unik di Indonesia dalam merayakan Idhul Fitri. 
Kamus Bahasa Indonesia https://oldi.lipi.go.id/public/Kamus\%20Indonesia.pdf hal 61 memberi arti ancaman n 1 sesuatu yang diancamkan: menganggap sepi $\sim$ itu; 2 perbuatan (hal dsb) mengancam: akan pembongkaran daerah itulah yang menggelisahkan penduduk. Jadi ancaman merupakan kata benda yang berarti sesuatu yang diancamkan atau perbuatan mengancam. Dalam iklan di atas, ancaman tidak hanya diemban kata "Jangan", tetapi juga melalui gambar yang menunjukkan bahwa, jika Anda mudik, maka seluruh diri Anda mengandung ganasnya virus Corona yang Anda bawa dari kota, dapat mengancam seluruh keluarga, bahkan juga mengancam nyawa orang-orang sekampung.

Berdasarkan konstruksi proposisi yang digunakan dalam iklan tersebut, maka konstruksi kepala iklan merupakan proposisi kondisional. Oleh karena makna iklan ini bersifat mengancam atau ancaman, maka konstruksi "Jika" dan "Maka" yang dilesapkan, sangat nyata dalam konstruksi tersebut. Proposisi kondisional dalam iklan tersebut secara lengkap berbunyi: “Jika ingin sehat, maka jangan mudik, karena Nikmat akan membawa sengsara". Hal tersebut juga tertera pada tubuh iklan yang berbunyi: "Jika Anda mudik, maka 700 ribu orang terancam terinfeksi”, "Jika Anda mudik, maka Anda seorang bisa tulari 406 orang dalam sebulan”, “Jika Anda mudik, maka Anda akan menulari orang tua yang $3 x$ lebih rentan terinfeksi".

Konstruksi "Jika" dan "Maka", menjadi konstruksi utama dalam menyusun proposisi kondisional sebagai salah satu karakteristik utama bahasa iklah layanan masyarakat. Iklan di atas dilengkapai pula dengan penutup iklan yang juga berkonstruksi proposisi kondisional yakni: "Jika ingin sehat, maka lindungi diri, orang tua, dan keluarga di kampung halaman dengan jangan mudik”.

4.1.2.d Iklan layanan Masyarakat Berkonstruksi Intimidatif: Ancaman:

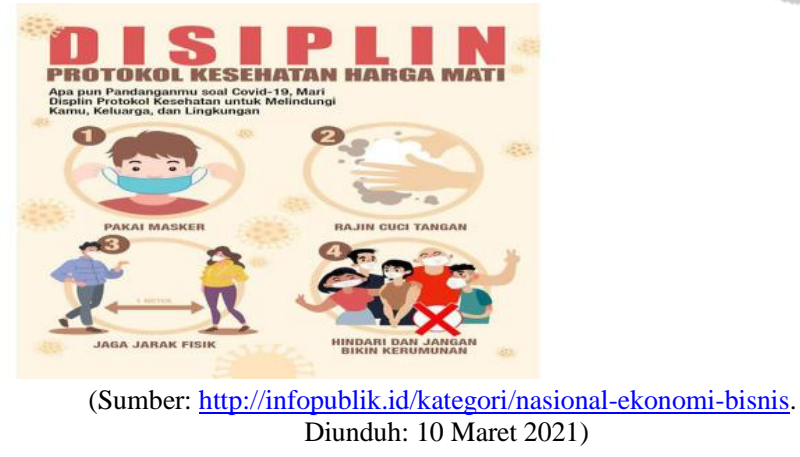


Sebagai sebuah iklan layanan masyarakat dengan konstruksi intimidatif varian ancaman, iklan di atas sangat tegas dan jelas dalam memberikan ancaman kepada masyarakat untuk patuh pada protokol kesehatan. Kepala iklan berbunyi: "DISIPLIN, PROTOKOL KESEHATAN HARGA MATI”. Jenis dan ukuran huruf pada kata DISIPLIN, dibuat sangat besar dengan huruf kapital. Berdasarkan rasa bahasa, kata yang ditulis dengan huruf kapital bermakna mengancam untuk memunculkan rasa takut pada orang yang membacanya. Dalam Bahasa lisan, jenis dan ukuran huruf tersebut memberikan gambaran bahwa si pembicara sedang marah dan berteriak untuk berdisiplin pada protokol kesehatan. Di masa pandemi Covid-19, disiplin adalah harga mati dan protokol kesehatan juga harga mati.

Hal tersebut juga ditegaskan melalui tubuh iklan yang berbunyi: “Apapun pandanganmu soal Covid-19, Mari disiplin protokol kesehatan untuk melindungi kamu, keluarga, dan lingkungan”. Disiplin protokol kesehatan tersebut juga dirinci atas 4 frase yang dilengkapi ilustrasi gambar sebagai penegasan seperti:

(1) "Pakai masker";

(2) "Rajin cuci tangan";

(3) "Jaga jarak fisik";

(4) "Hindari dan jangan bikin kerumunan".

Keseluruhan tubuh iklan tersebut ditulis dengan hanya menggunakan kata dasar. Hal ini bertujuan mempertajam sifat intimidasi varian ancaman tersebut. Jika diberi imbuhan, maka sifat intimidatif yang mengancam tersebut akan berubah menjadi persuasi varian ajakan atau bujukan. Konstruksi yang dipandang sangat halus untuk sebuah himbauan yang sasarannya adalah mengubah perilaku masyarakat.

Secara proposisional, konstruksi di atas berkategori kondisional yang dapat dilihat dari rangkaian kata yang membentuk proposisi dalam iklan tersebut. Lengkapnya, konstruksi itu berbunyi: “Jika Anda ingin sehat, maka protokol kesehatan adalah harga mati”. Lengkapnya konstruksi proposisi kondisional yang mensaratkan penggunaan "Jika" dan "Maka", akan menghilangkan salah satu karakteristik bahasa iklan, yakni, singkat dan padat. Konstruksi "Jika" dan "Maka" terpaksa diabaikan atau dilesapkan, demi sifat intimidatif varian ancaman yang digunakan iklan tersebut demi menata perilaku masyarakat untuk taat protokol kesehatan. 
Konstruksi "Jika" dan "Maka" juga dilesapkan dalam tubuh iklan 4.1.2.d yakni:

(1) "Jika ingin sehat, maka Pakai masker";

(2) "Jika ingin sehat, maka Rajin cuci tangan";

(3) "Jika ingin sehat, maka Jaga jarak fisik";

(4) "Jika ingin sehat, maka Hindari dan jangan bikin kerumunan".

4.1.2.e Iklan layanan Masyarakat Berkonstruksi Intimidatif: Ancaman:

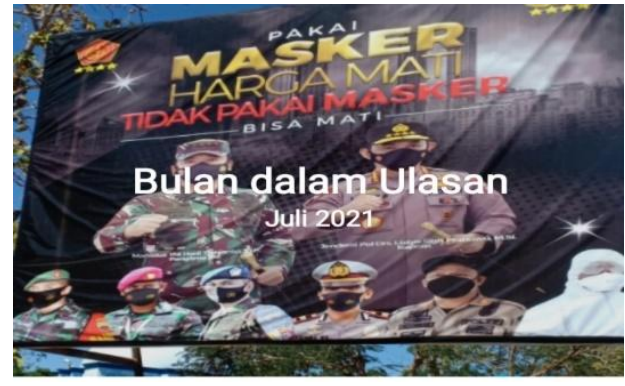

Sumber: Baliho TNI di Perempatan Penfui-Naimata.Kupang NTT

Konstruksi intimidatif varian ancaman dalam iklan di atas sangat tegas tanpa kepala iklan, melainkan secara langsung dan lugas memaparkan pesan penting yang merupakan tubuh iklan tersebut. Iklan yang berbunyi: “Pakai Masker Harga Mati, Tidak Pakai Masker Bisa Mati”, ditulis oleh Angkatan Bersenjata Republik Indonesia, baik Angkatan darat, laut, dan udara. Ketegasan tersebut pada dasarnya mencerminkan sikap tegas ABRI dalam memerangi Covid-19 yang tidak hanya mengancam nyawa, tetapi sudah melakukan pembunuhan massal. Oleh karena itu, dibutuhkan sikap tegas dalam mengayomi dan melindungi masyarakat dari berbagai bahaya termasuk Covid-19.

Berdasarkan pola proposisi, iklan di atas juga berkonstruksi kondisional, yang meskipun pola “Jika" dan "Maka” tidak dieksplisitkan, namun sangat jelas terbaca melalui ketegasan kondisi yang menjadi ancaman dalam iklan di atas. Apabila dinyatakan secara eksplisit, maka iklan di atas berbunyi: : “Jika ingin hidup sehat, maka Pakai Masker Harga Mati, Tidak Pakai Masker Bisa Mati”. Kriteria bahasa iklan yakni singkat, jelas, dan padat, sangat diperhitungkan, sehingga konstruksi “Jika ingin hidup sehat, maka...” kemudian dilesapkan dalam penulisan iklan tersebut.

Di sisi lain, meskipun konstruksi di atas berjenis intimidatif varian ancaman, namun pilihan kata melalui pengulangan kata “Mati” menimbulkan pemahaman yang tegas pula dalam diri pembaca, yakni masyarakat yang menjadi sasaran iklan tersebut. Kesarkaisan kata “Mati” menjadi berkurang oleh adanya pola formulaik melalui "Harga Mati" dan "Bisa Mati”. Meskipun tetap bervarian ancaman, namun ketegasan sikap Angkatan Bersenjata RI 
dalam menjaga NKRI, yang menjadi semboyan TNI yakni “NKRI Harga Mati” juga menjadi inspirasi dalam penulisan iklan 4.1.2.e.

\subsection{Pembahasan Hasil Penelitian}

Iklan merupakan media penyaluran pesan-pesan penting kepada masyarakat atau konsumen. Kecenderungan iklan bersifat persuasif bahkan intimidatif, artinya mengajak atau mengancam masyarakat agar menggunakan produk atau patuh pada instruksi yang diiklankan melalui pilihan kata dan kalimat dalam ikkan tersebut. Sebuah iklan dirancang untuk mempengaruhi pola pikir dan pola perilaku masyarakat agar menanggapi iklan yang disampaikan.

Hasil penelitian yang dilakukan menunjukkan bahwa terdapat dua konstruksi dalam bahasa iklan layanan masyarakat pada masa pandemi Covid-19. Kedua konstruksi tersebut adalah persuasif dan intimidatif yang pada umumnya berkonstruksi proposisi kondisional yang biasanya merupakan proposisi dengan kalimat perintah atau instruksi. Pola kalimat pada konstruksi proposisi kondisional mau menyatakan bahwa proses belajar manusia itu sangat kompleks, sebab manusia terlibat dalam berbagai jenis pembelajaran seperti partisipasi, menghubungkan ide-ide, dan menalar. Dengan kemampuan mengoneksi ide-ide, menganalisis, dan menalar, manusia membentuk pola perilaku dalam mengoptimasi perkembangan dirinya. Dalam kaitan dengan upaya Pemerintah membina dan membentuk tatanan hidup baru masyarakat melalui iklan layanan masyarakat terutama tentang pola hidup bersih dan sehat, maka berikut dipaparkan beberapa kaidah yang berkaitan dengan konstruksi proposisi kondisional. Konstruksi-konstruksi tersebut digunakan untuk merumuskan makna yang terkandung di dalamnya dalam rangka pembentukan kebiasaan baru sebagai perilaku masyarakat.

Kemampuan mengoneksi ide-ide, menganalisis, dan menalar, manusia membentuk pola perilaku dalam mengoptimasi perkembangan dirinya sejalan dengan proposisi hipotesis yang memiliki 3 jenis seperti yang dikutip peneliti dari Samhis Setiawan (2021, melalui https://www.gurupendidikan.co.id/. Ketiga jenis proposisi hipotesis tersebut adalah proposisi kondisional, proposisi disyungtif, dan proposisi konjungtif. Dari ketiga jenis proposisi tersebut, jenis yang paling sering digunakan pada iklan layanan masyarakat pada masa pandemic Covid-19 adalah jenis yang pertama yakni proposisi kondisional. Proposisi ini menjelaskan sifat ketergantungan antara dua proposisi, yakni proposisi yang satu pasti mengikuti proposisi yang lain karena ada suatu kondisi tertentu. Bila syarat terpenuhi maka 
kebenaran terjadi, sebaliknya, jika syarat tidak terpenuhi maka kebenaran tidak terjadi yang dirumuskan melalui pola ...jika...maka... .

Makna iklan layanan masyarakat pada masa pandemi Covid-19 berkaitan langsung dengan dua jenis konstruksi iklan yakni konstruksi persuasif dan intimidatif dengan berbagai variannya. Konstruksi persuasif memiliki 2 varian yakni membujuk atau mengajak dan memengaruhi. Sedangkan konstruksi intimidatif juga memiliki dua varian yakni perintah atau instruksi serta ancaman. Oleh karena isu utama penelitian ini adalah konstruksi proposisi kondisional dalam iklan layanan masyarakat pada masa pandemi Covid-19, maka pembahasan hasil penelitian akan difokuskan pada konstruksi tersebut.

Sama halnya dengan peran guru di ruang kelas, di ruang publik Pemerintah juga berperan mendidik dan membelajarkan masyarakat melalui cara-cara yang halus sampai yang bernada mengancam. Pembelajaran yang dilakukan Pemerintah di ruang publik pada masa pandemi Covid-19, salah satunya adalah melalui iklan layanan masyarakat. Oleh karena tidak semua anggota masyarakat memiliki mental yang mudah diatur dan sadar bahwa kesehatan sangat penting, maka melalui media iklan, Pemerintah selain melakukan persuasi, juga melakukan intimidasi.

\section{SIMPULAN}

Dengan merujuk pada konstruksi kalimat penalaran atau proposisi, peneliti memperoleh simpulan bahwa, iklan layanan masyarakat pada masa pandemi Covid-19 pada umumnya disusun dengan menggunakan konstruksi proposisi kondisional. Proposisi ini menjelaskan sifat ketergantungan antara dua proposisi, yakni proposisi yang satu pasti mengikuti proposisi yang lain karena ada suatu kondisi tertentu. Bila syarat terpenuhi maka kebenaran terjadi, sebaliknya, jika syarat tidak terpenuhi maka kebenaran tidak terjadi yang dirumuskan melalui pola ... jika...maka... . Dengan memilih proposisi hipotesis jenis proposisi kondisional, peneliti menemukan relasi yang sejajar antara logika berbahasa dengan jenis proposisi kondisional dengan prinsip pengondisian yang digagas Edward Thorndike (1913 dalam Schunk, 2012: 101).

Berdasarkan konstruksi proposisi kondisional, ditemukan 2 jenis konstruksi dalam iklan layanan masyarakat pada masa pandemik Covid-19, yakni konstruksi proposisi kondisonal yang bersifat persuasif dan konstruksi proposisi kondisional yang bersifat intimidatif. Konstruksi persuasif memiliki 2 varian yakni, membujuk dan membujuk atau 
mengajak, dan memengaruhi. Konstruksi intimidatif memiliki 3 varian yakni larangan, perintah, dan ancaman.

Makna konstruksi proposisi kondisional dalam iklan layanan masyarakat secara langsung mengikuti konstruksi tersebut yakni bermakna persuasif dan intimidatif. Kalimat persuasif dalam iklan dengan makna membujuk merupakan ajakan yang sangat halus agar pembaca mau mengikuti ajakan, saran bahkan perintah atau larangan. Selain membujuk, kalimat persuasif juga bersifat mengajak agar pembaca mau bersama-sama mematuhi anjuran atau perintah yang terdapat dalam kalimat iklan tersebut. Apabila hal yang diiklankan berkaitan dengan barang atau produk tertentu, maka sifat-sifat persuasi tersebut bertujuan agar khalayak pembaca meminati barang atau produk yang ditawarkan si pembuat iklan. Sebuah kondisi yang ditawarkan Pemerintah agar masyarakat dapat hidup dalam kondisi yang sehat selama dan pasca pandemic Covid-19.

Makna konstruksi intimidatif juga mengikuti arti kata intimidasi dalam Kamus besar Bahasa Indonesia (KBBI) yang masuk ke dalam kelas kata nomina (kata benda). Arti yang pertama adalah tindakan menakut-nakuti (terutama untuk memaksa orang atau pihak lain berbuat sesuatu). Arti kedua adalah gertakan, dan arti ketiga adalah ancaman (Dikutip dari https://lektur.id tanggal 01 Oktober 2021). Ketiga arti kata intimidasi tersebut dikategorikan sebagai varian intimidasi, terutama melarang yakni memaksa orang atau pihak lain untuk berbuat atau tidak berbuat sesuatu. Varian lainnya adalah perintah yang juga dapat disamakan dengan gertakan agar orang atau pihak lain mau melakukan sesuatu dengan patuh dan taat kepada perintah tersebut.

\section{DAFTAR PUSTAKA}

Amsari, Dina \& Mudjiran. 2020. Implikasi Teori Belajar E. Thorndike (Behavioristik) dalam Pembelajaran Matematika. Jurnal Basicedu research \& Learnigin Elementary Education. Tersaji pada Laman https://jbasic.org/index.php/basicedu. Diunduh 15 Maret 2021).

Anonimous (melalui https://eprints.uny.ac.id/) mengutip (Mulyana, 2005)

Badan Pengembangan dan Pembinaan Bahasa, Kementerian Pendidikan dan Kebudayaan

Republik Indonesia, 2016: melalui laman https://kbbi.kemdikbud.go.id/entri/bujuk).

Bolen (dalam Rani, Dkk. 2004, tersaji melalui http://eprints.umm,ac.id, dikutip tanggal 03 Agustus 2021

brainly.co.id (dikutip tanggal 27 July 2021)

https://kbbi.web.id/persuasif.html (tanggal 27 July 2021)

https://lektur.id tanggal 01 Oktober 2021

Iklan Layanan Masyarakat. 2020. Tersaji pada Laman: https://promkes.kemkes.go.id/ilm-terkait- pencegahancovid-19. Diunduh: 15 Maret 2021) 
Iklan Layanan Masyarakat. 2020. Tersaji pada Laman: Komisi Penyiaran Indonesia: http://www.kpi.go.id/index.php/id/umum/38: Diunduh: 15 Maret 2021.

Iklan Layanan Masyarakat. 2020. Tersaji pada Laman: www.liputan6.com, Diunduh: 15 Maret 2021)

Iklan Layanan Masyarakat. 2020. Tersaji pada Laman: http://infopublik.id/kategori/nasionalekonomi-bisnis. Diunduh: 10 Maret 2021.

Mustaji. 2018. Paradigma Pembelajaran Era Revolusi Industri 4.0. Surabaya. FIP Unesa.

Nai, Firmina Angela. 2017. Pengembangan Modul Mata Kuliah Belajar dan Pembelajaran dengan Model Lesson Study Berbasis Learning Community untuk Mahasiswa Semester II Program Studi Pendidikan Bahasa dan Sastra Indonesia FKIP Undana. Disertasi Teknologi Pembelajaran Universitas Negri Malang.

Kamus Bahasa Indonesia https://oldi.lipi.go.id/public/Kamus\%20Indonesia.pdf

Kamus Besar Bahasa Indonesia versi online pada laman: https://kbbi.web.id/konstruksi, dikutip Tanggal 03 Agusutus 2021).

Keputusan Menteri Kesehatan Republik Indonesia Nomor hk.01.07/menkes/382/2020 tentang Protokol Kesehatan bagi Masyarakat di Tempat dan Fasilitas Umum dalam Rangka Pencegahan dan Pengendalian Corona Virus Disease 2019 (Covid-19). Diunduh Tanggal 10 Maret 2021.

Samhis Setiawan (2021, melalui https://www.gurupendidikan.co.id/ dikutip tanggal 04 Agustus 2021) 